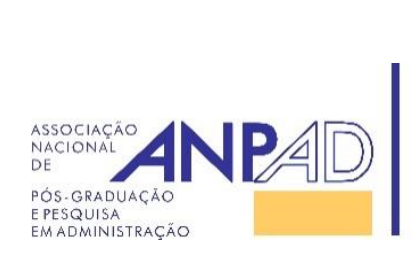

Disponível em

http://www.anpad.org.br/rac

RAC, Rio de Janeiro, v. 20, n. 6, art. 1, pp. 651-672, Nov./Dez. 2016

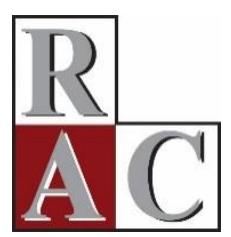

\title{
Lending Groups and Different Social Capitals in Developed and Developing Countries
}

\author{
Diego A. B. Marconatto 1 \\ Luciano Barin-Cruz ${ }^{2}$ \\ Eugenio Pedrozo ${ }^{3}$
}

Universidade do Vale do Rio dos Sinos ${ }^{1}$ HEC Montréal ${ }^{2}$ Universidade Federal do Rio Grande do $\mathrm{Sul}^{3}$

Artigo recebido em 04.03.2015. Última versão recebida em 19.02.2016. Aprovado em 24.02.2016. Publicado online em 09.08.2016. 


\title{
Resumo
}

Grupos de empréstimo (GEs) e capital social são elementos primordiais para as muitas soluções em operações de microfinanças ao redor do mundo. No entanto, a capacidade dos GEs para reduzir os custos e os riscos de transações das instituições de microfinanças (IFM) são mediados pelo ambiente institucional. A partir desse pressuposto, discutimos as interações existentes entre os ambientes institucionais dos países desenvolvidos (anglosaxões e comunitários) e os países em desenvolvimento com diferentes estoques de capital social (individual, em rede e institucional), bem como as influências dessa interação sobre a eficácia dos GEs. Para tanto, construímos, a partir da perspectiva institucional de O. Williamson, um framework teórico que coloca em interação todos esses elementos e que permite analisar as suas principais relações dentro do contexto deste estudo. Com base nesse framework, propomos que, nos países em desenvolvimento e nos países anglo-saxões, tanto o estoque de capital social individual quanto o em rede são os mais importantes para a eficácia dos GEs. No entanto, em países anglosaxões, esses dois estoques de capital social são complementados por dispositivos formais de contratação. Nos países comunitários desenvolvidos, porém, os estoques de capital social institucional têm um impacto positivo mais forte sobre a dinâmica dos GEs.

Palavras-chave: microfinança; grupos de empréstimo; capital social; ambiente institucional.

\begin{abstract}
Lending groups (LGs) and social capital are two central elements to the many microfinance solutions operating around the world. However, LG effectiveness in reducing transaction costs and lending risks for microfinance institutions (MFIs) is mediated by institutional environments. Starting from this assumption, we discuss the existent interactions between the institutional environments of developed (Anglo-Saxon and communitarian) and developing countries with different stocks of social capital (individual, network and institutional) and the influences of this interaction on LG effectiveness. In order to do so, we applied the institutional perspective of O. Williamson to build a theoretical framework to examine the interaction of all these conditions, allowing for analysis of their main relations within the microfinance context. Based on this framework, we propose on the one hand that in developing and Anglo-Saxon developed nations, stocks of both individual and network social capital are the most important for an LG's effectiveness. However, in Anglo-Saxon countries, these two stocks of social capital are complemented by formal contracting devices. In communitarian developed countries, on the other hand, the stocks of institutional social capital have a stronger positive impact on LG dynamics.
\end{abstract}

Key words: microfinance; lending groups; social capital; institutional environment. 


\section{Introduction}

Microfinance institutions (MFIs) - briefly defined as organizations devised to offer small financial and finance-related services to poor families - are currently recognized as consolidated strategies in the fight against poverty, and have multiplied throughout the world. A common client model in microfinance is the lending group (LG) - a semi-formal group of individual loan seekers. LG methodology plays a fundamental role within these institutions, embodying the central mechanics of the majority of the MFIs currently operating in most countries and world regions (Bhatt \& Tang, 1998; Bhattamishra \& Barrett, 2010; Ghatak, 1999, 2002; Stiglitz, 1990). The LGs' key contribution is a micro institutional arrangement that reduces transaction costs for both borrowers and MFIs, such that the impoverished individuals occupying the bottom of the pyramid - a priori considered non bankable become capable of solvency. However, the simple adoption of the LG methodology does not guarantee the success of the lending operations oriented towards disenfranchised clients, since a LGs' capability to reduce transaction costs is affected by the institutional environment and the social capital surrounding the MFIs (Bhatt \& Tang, 1998; Ghatak, 1999).

Many researchers (e.g. Bhatt \& Tang, 1998; North, 1991; Putnam, 1993) have demonstrated that both formal and informal institutions in developed and developing countries can positively or negatively affect the ability of borrowers to alleviate both the risks borne by the MFIs - exacerbated by the condition of information asymmetry - and the difficulties of enforcing contracts (Stiglitz, 1990). Moreover, it is known that social capital, understood roughly as goodwill embedded within social relations (Adler \& Kwon, 2002), carries the potential to ameliorate the quality of the information exchanged between borrowers and MFIs and to increase the capability of these organizations for enforcing loan repayment (Bastelaer, 1999a). These findings support the belief that the creation and utilization of stocks of social capital increase the efficiency of microfinance operations (Bastelaer, 1999a, 1999b; Bhatt \& Tang, 1998; Ghatak, 2002; Ghatak \& Guinnane, 1999; Larance, 1998; Rankin, 2002).

To the best of our knowledge, there are no studies that have considered how the interaction between the institutional environment (of developed and developing countries) and the stocks of social capital considered in their different forms (individual, network and institutional) influence an LG's capability for reducing the transaction costs and risks for MFIs. The work of Bhatt and Tang (1998) might represent an exception, but they have approached the issue by considering social capital only in general terms, whereas it is recognized that this resource exists in different forms which dwell in different structures of social reality (Ostrom, Ahn, \& Olivares, 2003; Serageldin \& Grootaert, 2000).

We argue that analyzing LGs from this perspective may contribute to improvements in the design and operation of private and public policies oriented towards the microfinance industry. Focusing on the interaction between institutional environments and the different stocks of social capital may also provide insights into the most appropriate types of social capital for improving the efficiency of LG functionality in developed and developing countries. Moreover, one of the main causes of premature failure of these organizations is the simple replication of what is held as the best MFI model, without considering the effects of institutional and social discrepancies between the incumbent and the recipient countries (Churchill, 1999; Lavoie, 2009). We hope that the present study may help policymakers and practitioners to avoid such strategic mistakes, by illustrating the main pitfalls and opportunities arising from such a transplantation approach.

In this paper, therefore, we intend to explore the interaction between the type of institutional environments (developed and developing countries) and the different stocks of social capital (individual, network and institutional) and how this affects the ability of an LG to diminish the transaction costs and risks borne by the MFIs. We used the institutional construction of reality devised by Williamson (2000) to create a theoretical framework for understanding the dynamic relationship among the systematization of the LG methodology, the different institutional environments and the different stocks of social capital within them. 
The key interactions and influences that emerge from this study represent this paper's main contribution: the proposition that the institutional environments of the developed (both Anglo-Saxon and communitarian) countries and the developing countries require different stocks of social capital to maximize LGs' efficiency in reducing transaction costs and risks for MFIs. We will argue that, on the one hand, in the developing institutional contexts and in the Anglo-Saxon developed contexts, the individual and network social capitals are the most important for LGs' efficiency maximization. In the Anglo-Saxon countries, these two stocks of social capital are complemented by formal contractual mechanisms. In contrast, in the communitarian developed countries, the institutional social capital is expected to have the most important impact on LG performance.

\section{Lending Groups (LGs), and their Relation to the Institutional Environments of Developing and Developed Countries and the Different Stocks of Social Capital}

The ability of LGs to reduce the transaction costs and risks borne by MFIs is influenced by the stocks of social capital carried by their individual borrowers, by the LGs themselves (set up as a social network formed by their borrowers) and by the institutional environment (Bastelaer, 1999a; Cassar, Crowley, \& Wydick, 2007). Characteristics of the surrounding institutional environment, such as legal efficiency, social values, norms and culture, also affect the potential of these collective arrangements for improving the flow and quality of information available to MFIs, as well as improving their capability to enforce their rules over their borrowers (Stiglitz, 1990).

Nevertheless, the existing literature has not explored (a) how the different stocks of social capital (individual, network and institutional) and the institutional environments of developed versus developing countries affect each other, and (b) how this relationship between the stocks of social capital and institutional environments impacts, in turn, LG capacity for reducing the transaction costs and risks for MFIs. In this paper, we provide a theoretical perspective to this discussion. In Figure 1, we present the constitutive elements of our proposition, explained throughout the next sections. 


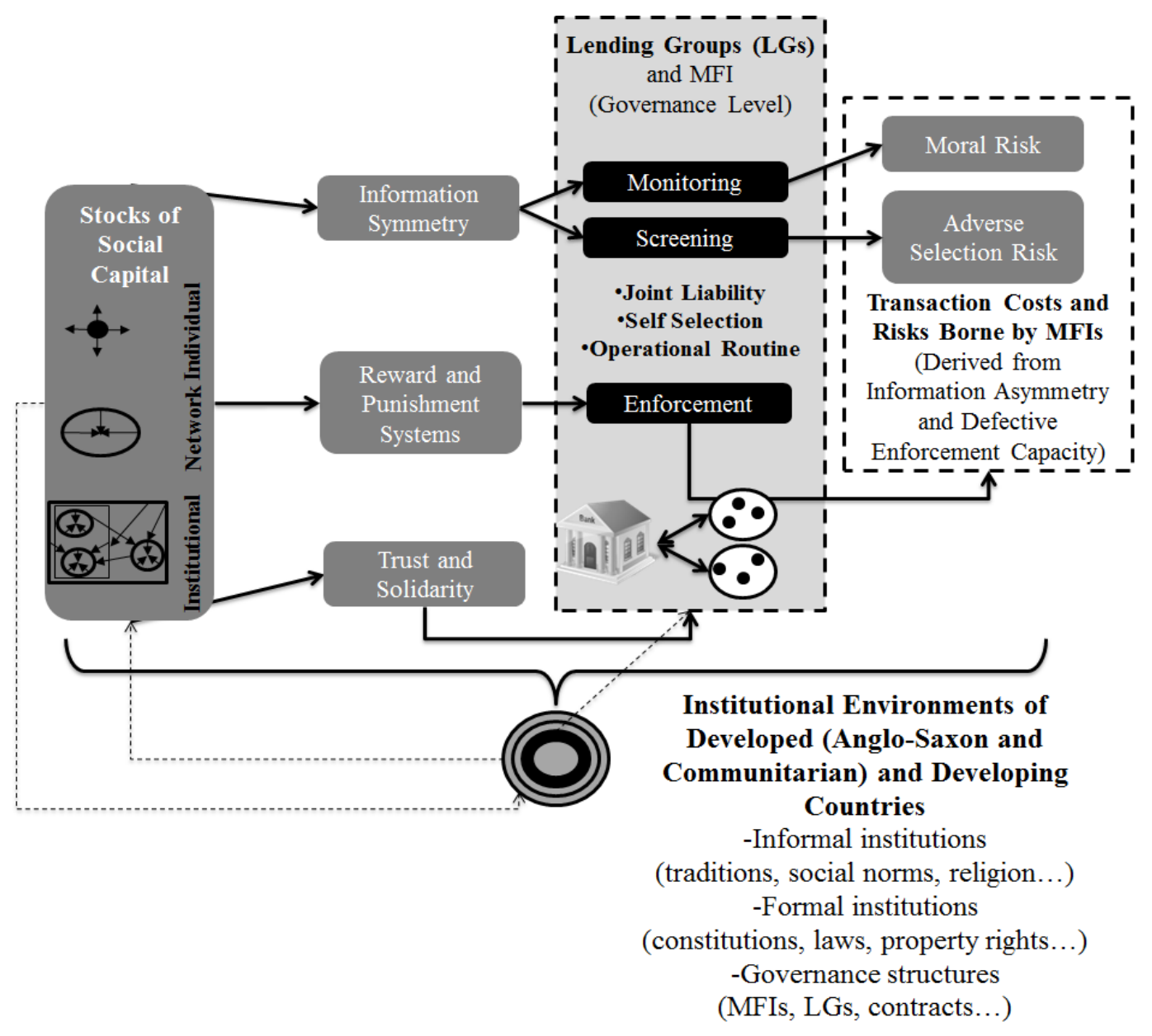

Figure 1. Effects of the Relations between the Three Stocks of Social Capital and the Institutional Environments of Developed and Developing Countries over LGs' Capacity for Diminishing Transactions Costs and Risks for MFIs

In the next section, we explain why the poor are excluded from formal credit markets. Later, we show how LG methodology and MFIs are able to overcome these obstacles. In the third section, we present the main characteristics of an institutional environment and the different stocks of social capital. In the fourth section, we describe how the interaction between the different institutional environments (developed and developing countries) and the three stocks of social capital affect LGs' ability to diminish the transaction costs and risks faced by MFIs.

\section{Moral and adverse selection risks: the credit dilemma and the exclusion of the poor from the formal credit markets}

The gains accrued by lenders and borrowers engaged in credit transactions depend heavily on the ability of these actors to reduce the risks involved in their exchange relations (Pischke, 1991; Stiglitz, 1987). However, it happens that the systematic exposure to a variety of risks is one of the determining characteristics of poverty (Collins, Morduch, Rutherford, \& Ruthven, 2009). Therefore, in order to diminish the associated transactional risks, banks oriented towards poor borrowers must absorb the high transaction costs incurred in the design and performance of risk reduction activities - in other words, the costs involved in the screening of less risky borrowers, in the monitoring of active borrowers and eventually in the enforcement of contracts of insolvents (Stiglitz \& Weiss, 1981). In order to cover these additional costs, these banks must charge higher loan interest rates. As we will see later, more expensive loans will, paradoxically, reinforce the same risks that these lenders are trying to diminish. This dilemma 
of credit, technically known as economic equilibrium with credit rationing (Stiglitz \& Weiss, 1981), is the economic factor motivating the exclusion of the poor from the formal credit markets.

Two transactional risks borne by the MFIs - moral and adverse selection risks - derive from the information asymmetry between these organizations and their borrowers and the defective enforcement capability of the former (Tassel, 1999). According to the same author, the lower the flow and the quality of the information exchanged between the two sides and the lower the lender agent's enforcement capability, the higher both risks will tend to be.

"Adverse selection risk arises when borrowers have characteristics that are unobservable to the lender but affect their probability of being able to repay the loan" (Ghatak \& Guinnane, 1999, p. 200). As long as the lender does not have all the information about the borrowers the adverse selection risk hinders the screening for safe clients versus risky clients and consequently, precludes their individualized management. Thus, the lender may try to screen his/her clients indirectly, by establishing loan conditions that only safe clients would be willing to accept (Stiglitz \& Weiss, 1981).

Moral risk, or moral hazard, is the situation in which the borrower can get involved in activities that increase his/her probability of defaulting because the risks are completely or, at least, partially borne by the lender (Pischke, 1991; Sengupta \& Aubuchon, 2008). Simply put, moral risk exists whenever a borrower, knows that ultimately someone else - for example, the lender - will bear the cost for any unpaid loans. Thus, moral risk creates an incentive for the lender's clients to choose riskier or more opportunistic projects and actions (Stiglitz \& Weiss, 1981). According to Ghatak and Guinnane (1999), the borrower is expected to behave such that the marginal benefit of his/her actions is the same or higher than his/her marginal cost. This means that the higher the interest rate contracted by a borrower, the higher will be the incentive to engage in more risky ventures in order to increase the payoff.

There is yet a third element to this equation: the lender's enforcement capability. Enforcement means the ability to execute the loan contracts previously accorded to the borrowers (Bhattamishra \& Barrett, 2010; Hung, 2006; Stiglitz, 1990). The absence or insufficient level of enforcement is expected to act as positive feedback to the moral and adverse selection risks, in that the absence of any sanctions against delinquent behavior encourages borrowers to engage in opportunistic behavior (Bhatt \& Tang, 1998; Ghatak, 1999; Ghatak \& Guinnane, 1999).

If the lender decides to increase both his/her enforcement capability and his/her information symmetry (the knowledge about his/her potential borrowers' characteristics), he/she will be able to discriminate the risky clients from the safe clients and to design specific contractual devices for each of these groups, thereby reducing default risk (Stiglitz \& Weiss, 1981).

As shown in Figure 1, information symmetry is increased by the systematization of two activities: the screening and monitoring of the lender's clients (Spence, 1973; Stiglitz, 1990; Stiglitz \& Weiss, 1981). Increasing the lender's enforcement capability, in turn, relies on both social (Granovetter, 2005) and institutional (Williamson, 2000) factors, as well as on the type and extension of the contractual mechanism established between the parties engaged in the transaction (Stigler, 1970).

However, the design and implementation of information management (Grossman \& Stiglitz, 1980) and enforcement (Stigler, 1970) devices imply added costs. The costs related to client screening, monitoring and contract enforcement increase the total operational costs of the lender who must then offset these additional expenditures with higher interest rates (Stiglitz \& Weiss, 1981). In addition, this increase in the cost of loans drives off the safe clients and attracts the risky clients to the lender, justifying the credit rationing mechanism (Stiglitz \& Weiss, 1981). As we present in the next topic, LGs offer an alternative to this credit dilemma.

\section{Lending groups as a solution for the credit dilemma}

A LG is a semi-formal group of individuals seeking loans. These groups render, among other benefits, a decrease in the moral and adverse selection risks and an increase in the enforcement capability 
in credit transactions (Stiglitz, 1990; Tassel, 1999), without, however, necessitating an associated addition to the transaction costs (Bhatt \& Tang, 1998). Through the use of an innovative micro institutional arrangement harnessed to social capital dynamics, these groups foster the sharing - and eventual economizing - of lender transaction costs related to screening, monitoring and enforcement activities so that the overall cost and risk of transactions are diminished (Bhatt \& Tang, 1998). While the methodologies of different LGs are manifold, three characteristics seem to be present in the majority of them: joint liability, self-selection and unique operational routine (Table 1).

Table 1

The Three Key Characteristics of LGs

Key characteristics of LGs Details

Joint liability Joint liability is the first and the most celebrated LG characteristic (Bhattamishra \& Barrett, 2010; Ghatak \& Guinnane, 1999; Morduch, 1999). This device conditions the repayment terms of each borrower participating in an LG to the repayment performance of all of the LG's other borrowers (Ghatak, 1999). This means that these actors are held responsible not only for their own debts, but also for their LG peers' debts. If it happens that one of the borrowers does not repay his/her loan, the other LG participants will bear this cost, under the risk of having their access to future loans denied.

Self-selection The LGs are usually formed through previously existing social ties, such as neighbor group, friendship, and acquaintanceship. If a new borrower is being selected to join the group, whether to set it up or to substitute a former participant, he/she will be accepted into the LG only by full consensus, since all current borrowers will be held responsible for his/her debts in the event that he/she does not repay a loan (Ghatak, 1999).

Unique operational routine LGs are usually subjected to a schedule of frequent meetings - followed by visits from one or more of an MFI's credit agents - at which times its individual borrowers must each make small repayments (Bastelaer, 1999b). These meetings allow for better collective follow-up on the individual projects, better performance assessment and consequently, make for superior collective monitoring ability. Moreover, these meetings also facilitate the eventual sanctioning against (contract enforcement) delinquent borrowers and thereby, help to decrease the moral risk within the LG (Bastelaer, 1999b).

According to several authors (e.g. Bastelaer, 1999b; Bhatt \& Tang, 1998; Ghatak, 1999; Tassel, 1999), the mutual operation of these three characteristics provides certain benefits which could rarely be achieved by the MFIs themselves. Ghatak (2002), Stiglitz (1990) and Tassel (1999), for example, illustrate how the joint liable and self-selected LGs harvest local information to reduce the information asymmetry between the participants of the group and the MFI, thereby decreasing the levels of moral and adverse selection risks.

A key characteristic of LGs is their formation on a local level (Bastelaer, 1999a). Because an existing collective of borrowers will be responsible for delinquent loans of members, new participants will be selected with caution. The incumbent borrowers will thus use their historical knowledge of the applicant and the social and trust ties already existent between one another in order to choose the most reliable prospects (Ghatak \& Guinanne, 1999; Tassel, 1999). Thus, because borrowers are likely to know each other through direct personal experience prior to integration within the group, they are able to more accurately assess a potential borrower's risk of defaulting (Stiglitz, 1990).

Another benefit made possible by these mechanisms is the increased capability for enforcement of the lending contracts (Bastelaer, 1999a; Stiglitz, 1990). The acquaintanceship, the geographical proximity and the meetings with the other borrowers of the LG make it easier to render sanctions for ensuring the repayment of overdue installments (Yunus, 2007). Moreover, the joint liability is expected 
to encourage a higher solidarity among the LG's borrowers, considering that they share the common interest of diminishing the probability of default within their group (Yunus, 2007). This solidarity may foster the mutual assistance among these actors, increasing the odds of survival for their micro enterprises. At the same time, the LGs take advantage of what is called invisible collateral (Ghatak, 2002): the borrowers' reputations. Through development of a good reputation, borrowers can join better LGs, formed by safer prospects and offering more attractive loan conditions (e.g. lower interest rates and larger loans).

These social dynamics embedded within the LGs support the creation of a new micro institutional arrangement, which permits the decentralization of the screening, monitoring and enforcement activities (Morduch, 1999). LGs enable the MFI to share the execution of these three risk-reducing activities with its borrowers. This decentralization is expected to economize transaction costs for both borrowers and MFIs and to increase the efficiency of the screening, monitoring and enforcement activities (Bhatt \& Tang, 1998). Consequently, the risks may decrease, therefore permitting these organizations to extend credit to additional poor borrowers who were formerly excluded from the credit markets.

Nevertheless, merely adopting the LG methodology may not ensure that the aforementioned benefits materialize: the partial transference of the screening, monitoring and enforcement activities from the MFI to its borrowers may have null or even negative effects depending on the institutional context (Bastelaer, 1999a; Bhatt \& Tang, 1998; Ghatak, 1999). The governance of these activities must fit the external context of the MFI, since the cost and the feasibility of the institutional arrangements also depend upon their degree of compatibility with their surrounding environment (Williamson, 1991).

As we show in Figure 2, the LG's capability to absorb and increase the three risk reduction activities depends on its potential to (a) increase the flow and quality of the information on borrowers, (b) promote trust-based relationships and (c) create informal systems of reward and punishment. This potential is mediated by the institutional environment and by the different stocks of social capital embedded within it.

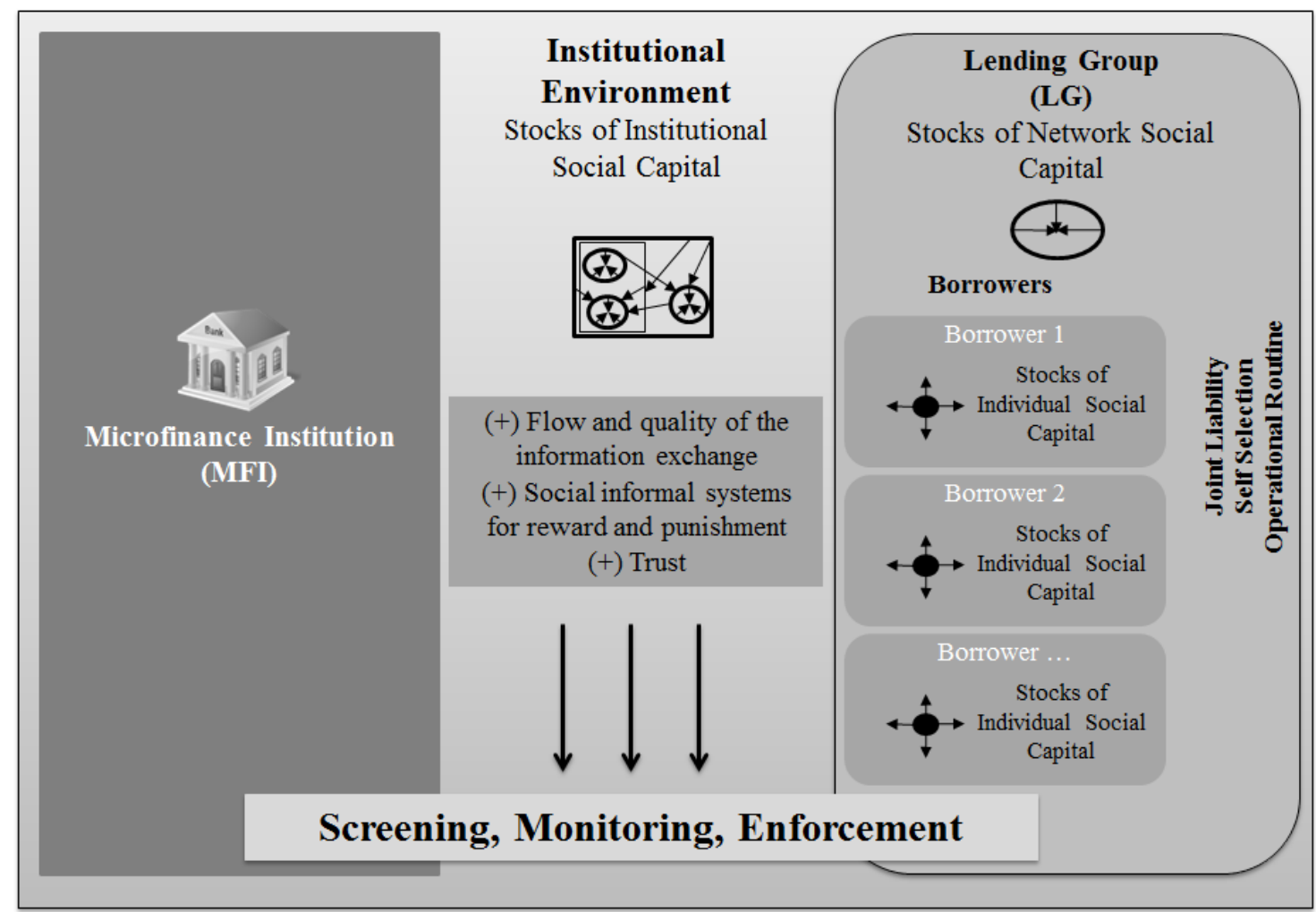

Figure 2. The Influences of the Institutional Environment and the Different Stocks of Social Capital on LGs' Capability for Diminishing the Transactions Costs and Risks of MFIs 


\section{Institutional Environment and the Stocks of Social Capital}

We illustrate the institutional environment of a given country - including the three different stocks of social capital and the microfinance institutional arrangements - through four overlapping and interconnected institutional circles (Figure 3). Within this representation, underpinned by Williamson's (2000) model, the larger institutional circle stands for the social hyper structure. The institutions at this level (customs, informal norms, and other deep-rooted ancient traditions) evolve over the centuries and their calculative character is almost nonexistent. Their effects over economy, society and formal institutions are profound and enduring (Williamson, 2000).
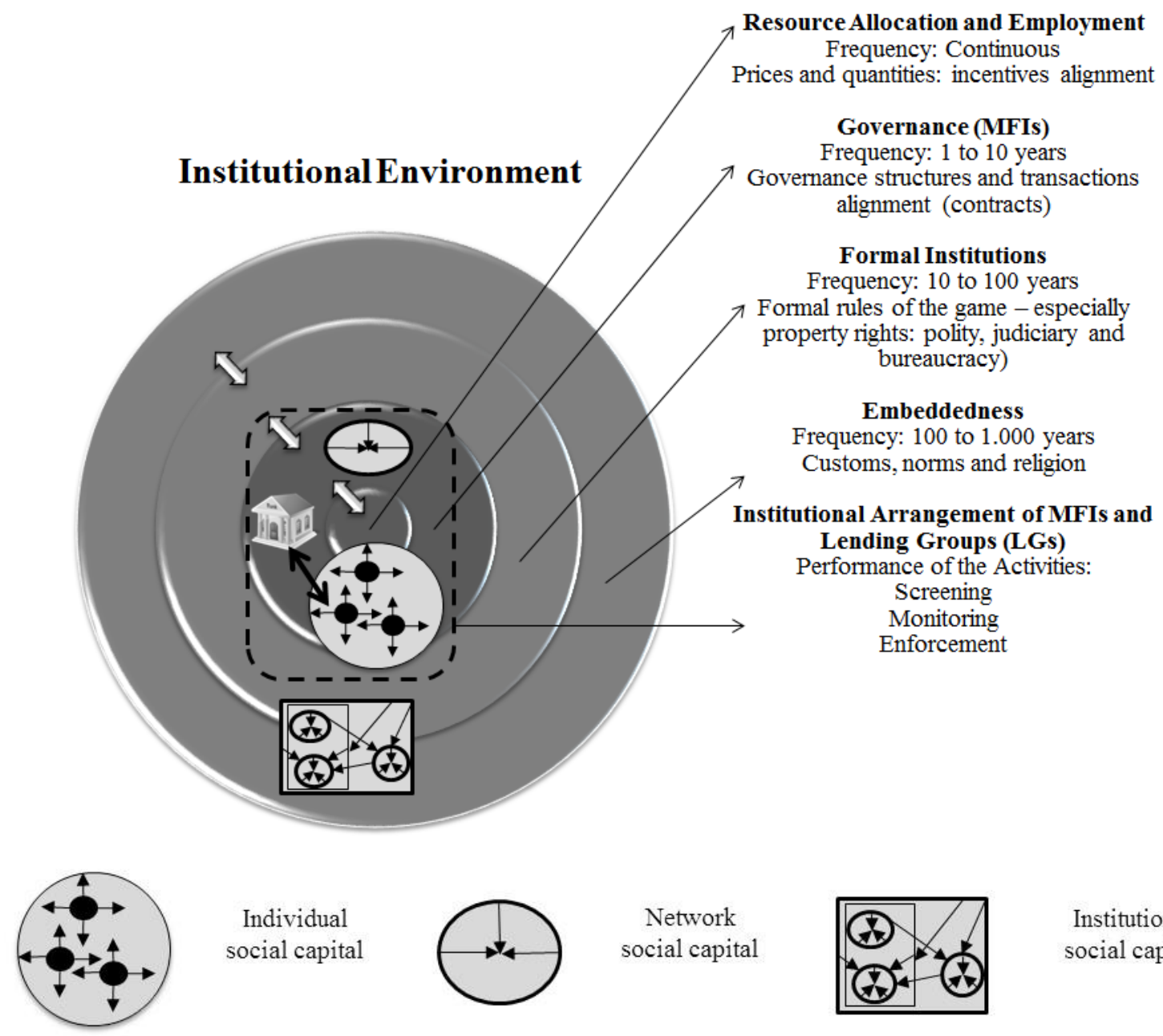

Individual social capital

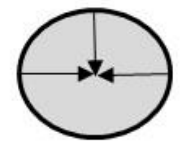

Network social capital

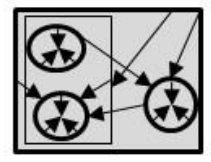

Institutional social capital

Figure 3. Institutional Environment of a Country, with the Three Different Stocks of Social Capital and the Microfinance Institutional Arrangements

The second institutional circle contains the formal institutions regulating the society. At this level, the institutions emerge from both informal historical phenomena (sanctions, taboos, customs, traditions and codes of conduct) and deliberate decisions. The formalized codes of conduct (constitutions, laws, property rights) and the distribution of formal power (executive, legislative and judiciary) are the most important institutions at this level. However, legislation designed to guarantee property rights - which Williamson (2000, p. 597) names "the formal rules of the game" - is not enough to cope with all specificities embedded within the plethora of economic and social transactions.

This insufficiency implies the necessity of a more accurate and immediate institutional level, that is, the governance level, which includes the "play of the game" (Williamson, 2000, p. 597). These transactions are coordinated by specific mechanisms of regulation: the contracts. These governance 
mechanisms embody the efforts made to create order, mitigate conflicts, yield mutual gains, and format the behavioral incentives of the involved actors. Also, changes within this institutional circle occur at a faster rate than they do at the two larger levels. The institutional arrangements of lending groups and MFIs are located within this level and will be approached in the next subtopic.

Social capital - goodwill mobilized to facilitate action localized within the flows of social relations (Adler \& Kwon, 2002) - is embedded in this institutional environment in different forms and might exist in its different circles as presented in Figure 3 and Table 2. In spite of the fact that there are many definitions for social capital (Adler \& Kwon, 2002; Portes, 1998; Swain, 2003), its positive effects converge towards three main influences exerted over the institutional environment, as presented in the framework outlined in Figure 1: increase in information symmetry, creation of formal and informal systems of reward and punishment, and fostering of trust and solidarity (Adler \& Kwon, 2002).

Table 2

\section{Stocks of Social Capital and Their Position within the Institutional Environment of a Country}

\begin{tabular}{|c|c|c|c|c|}
\hline $\begin{array}{l}\text { Social } \\
\text { Capital }\end{array}$ & $\begin{array}{l}\text { Institutional } \\
\text { Environment Level } \\
\text { (of the Country) }\end{array}$ & Function & Focus & $\begin{array}{l}\text { Examples of Positive } \\
\text { Effects* }\end{array}$ \\
\hline : & Human-mind level & $\begin{array}{l}\text { Resources of the } \\
\text { individual social } \\
\text { actors used to } \\
\text { obtain private gains }\end{array}$ & $\begin{array}{l}\text { Social actor and } \\
\text { his/her external } \\
\text { relations }\end{array}$ & $\begin{array}{l}\text { Larger access to social } \\
\text { groups and opportunities; } \\
\text { larger access to more and } \\
\text { better information; access to } \\
\text { more powerful positions. }\end{array}$ \\
\hline $\begin{array}{l}\frac{y}{10} \\
\vdots \\
0 \\
0 \\
z\end{array}$ & Governance level & $\begin{array}{l}\text { Resources of the } \\
\text { network used to } \\
\text { obtain collective } \\
\text { gains }\end{array}$ & Social networks & $\begin{array}{l}\text { Higher levels of trust, } \\
\text { collaboration, cooperation, } \\
\text { solidarity, density and } \\
\text { flexibility; less formal } \\
\text { controls. }\end{array}$ \\
\hline . & $\begin{array}{l}\text { Embeddedness and } \\
\text { formal institutional } \\
\text { levels }\end{array}$ & $\begin{array}{l}\text { Resources from the } \\
\text { institutional } \\
\text { environment used } \\
\text { to obtain multiple } \\
\text { gains }\end{array}$ & $\begin{array}{l}\text { Social networks } \\
\text { and formal and } \\
\text { informal } \\
\text { institutions }\end{array}$ & $\begin{array}{l}\text { Larger diffusion of } \\
\text { information; } \\
\text { horizontalization of social } \\
\text { structures; support of local } \\
\text { actions in their assessment, } \\
\text { monitoring and enforcement } \\
\text { activities; institutional } \\
\text { systems make it more } \\
\text { difficult for opportunism to } \\
\text { proliferate, which increases } \\
\text { general trust. }\end{array}$ \\
\hline
\end{tabular}

Note. Source: Elaborated from Adler, P. S., \& Kwon, S. (2002). Social capital: prospects for a new concept. Academy of Management Review, 27(1), 17-40. http://doi.org/10.2307/4134367; Ostrom, E., Ahn, T. K., \& Olivares, C. (2003). A social science perspective on social capital: social capital and collective action. Revista Mexicana de Sociologia, 65(1), 155-233. http://doi.org/10.2307/3541518; Serageldin, I., \& Grootaert, C. (2000). Defining social capital: an integrating view. In P. Dasgupta \& I. Serageldin, I. (Eds.), Social capital: a multifaceted perspective (pp. 40-58). Washington: World Bank.

* All connected to the increase of information symmetry, creation of formal and informal systems of reward and punishment, and to fostering of trust and solidarity.

Adler and Kwon (2002, p. 29) posit that "the first of social capital's direct benefits is information: for the focal actor, social capital facilitates access to broader sources of information and improves information's quality". The increase in the information symmetry fosters the densification of social networks (Coleman, 1988; Granovetter, 2005) and the creation of social institutions that are more horizontally structured. This strengthens the screening, monitoring and enforcement performed by the borrowers gathered in LGs (Besley \& Coate, 1995; Bhatt \& Tang, 1998; Ghatak, 1999; Ghatak \& Guinnane, 1999), since more and better information helps these actors select less-risky newcomers. 
These borrowers also have more resources for monitoring the behavior of their peers and predicting their repayment capabilities. Moreover, borrowers' individual characteristics might also increase the efficiency of the screening and monitoring activities performed within the LGs. Ostrom $(1998,2000)$, for instance, shows that some individuals participating in a collective action set may be spontaneous, collaborative and open.

Informal reward and punishment systems (enforcement), the second outcome of social capital, may also be created and strengthened by the three stocks of social capital. The social capital embedded within denser networks facilitates the indoctrination of rules, desirable behaviors and norms designed to maintain internal discipline and promote the acquiescence of its members (Granovetter, 2005). Because a more frequent repetition of social transactions makes for easier sharing, mimicking and absorption of these elements, the detection of delinquent behaviors is also facilitated, as is the use of social sanctions to punish them (Coleman, 1988; Granovetter, 2005; Portes, 1998). Social values, such as honor, communitarianism, and solidarity, embodied in the institutional social capital (Putnam, 1993) might also strengthen the social mechanisms of pressure eventually applied against delinquent borrowers. Finally, Ostrom $(1998,2000)$ suggests that individuals may naturally have a stronger tendency towards punitive measures when interacting within social groups. These people may voluntarily bear the personal cost of the punishment act applied against some deviant peer. This attitude is integral to the individual social capital, which may then increase the LGs' efficiency in the enforcement of delinquent borrowers' contracts.

Trust, the third positive outcome of social capital is expected to affect all screening, monitoring and enforcement activities. McEvily, Perrone and Zaheer (2003), for example, point out some organizing principles of trust which have a close relationship with the increase in the informational symmetry and the enforcement capability of the social arrangements: social network density, relational multiplexity, social network stability, non-redundancy of the network activities, sharing of network knowledge, intra-committment and loosening of safeguards. Ouchi (1980), Ebers (1999), Bachmann (2001), Adler (2001) and McEvily et al. (2003) also highlight the role of trust as a mechanism for reducing the use of formal control devices, with subsequent reductions in transaction costs.

Trust dynamics can be found at the individual, network or institutional levels. Granovetter (2005), for example, mentions that closer networks may increase the levels of mutual trust of their members and enhance the volume and quality of the information flowing among them. The shared trust takes the interacting borrowers to a higher level of mutual knowledge (screening and monitoring) and then offers an incentive to those actors to avoid opportunistic behaviors. The horizontal social institutions, in their turn, may at times nurture trust relations within the whole society (Ostrom, 1998; Putnam, 1993) and discourage opportunism in entire communities. This kind of society will be more likely, therefore, to be populated with collaborative individuals, who generally increase the governance efficiency of the collective arrangements (Ostrom, 2000; Ostrom et al., 2003).

These three benefits of social capital may be either causes or products of the institutional environment (Putnam, 1993). Because the individual frameworks, social networks and institutional environments influence each other and force replications or changes among themselves (Beckert, 2010), network social capital, for example, may support the emergence of institutions embedded with values and norms that facilitate the generalized goodwill (as a trust-based community, for example). Thus, these institutions, in turn, are expected to influence the cognitive frameworks of the individuals interacting with those institutions. Moreover, it is possible that stocks of individual social capital have a positive influence over the institutional social capital and the institutional context as a whole. Powerful actors endowed with the values that underpin social capital may use their privileged position within the political and social fabric to insert their mental model into large institutions such as government bodies and agencies (Greif, 1994; Fligstein, 2001).

But a general negative effect is also possible. For example, the rational individual behavior tending towards dysfunctional macro institutions feeds the dependency relations of mistrust and opportunism, may reinforce already existing social pathologies and reduce the positive potential of social networks and collaborative individuals for social action (Putnam, 1993). 
Another important point to highlight is the similarity between social capital and Williamson's (2000) economy of institutions with regard to the institutional levels and their time horizons. The stocks of social capital present or absent from the superior institutional circles are built or degenerated over longer periods of time and cannot be the products of intentional action. Moreover, these stocks of institutional social capital also condition the creation of the lower stocks of social capital (individual and network) and institutions (formal institutions and governance level). Putnam (1993, pp. 182-183), for example, mentions that:

the civic community [which has large stocks of institutional social capital] has deep historical roots. This is a depressing observation for those who view institutional reform as a strategy for political change ... Social context and history profoundly condition the effectiveness of institutions ... The social contract that sustains such collaboration in the civic community is not legal [formal institutional level] but moral [embeddeness level] ... Where norms [embeddeness level] and systems of civic engagement [formal institutional level] are lacking, the outlook for collective action [which take place in the governance level] appears bleak.

Therefore, divergent institutional histories unfold divergent consequences onto the contemporary institutions of developed and developing countries, which then affect both the LGs and the screening, monitoring and enforcement activities performed by them in different ways.

\section{Stocks of Social Capital, Institutional Contexts of Developed and Developing Countries and Their Influences on the Lending Groups}

We have presented the credit dilemma, how MFIs are able to overcome it through the use of the LG methodology, the structure of an institutional environment and the different stocks of social capital. Now we discuss how the interaction between the different institutional environments and the three stocks of social capital (individual, network and institutional) affects LGs' capability for diminishing MFIs' transaction costs and risks.

As we see in Table 3, the developed countries are subdivided into two groups: the Anglo-Saxon and communitarian nations. These two sets of countries were founded upon different ontologies of community, and hold different, deeply rooted beliefs about how the social and economic institutions should be built and governed. Thus, we will first present the contexts for developing countries followed by discussion of the Anglo-Saxon and communitarian contexts. 
Table 3

\section{Institutional Environments of Developed and Developing Countries (Embeddedness and Formal Institutional Level)}

\begin{tabular}{lll}
\hline Institutional Environments & Main Characteristics \\
\hline $\begin{array}{l}\text { Developed } \\
\text { Countries }\end{array}$ & $\begin{array}{l}\text { Anglo-Saxon* } \\
\text { (free market economies) }\end{array}$ & $\begin{array}{l}\text { Robust and reliable legal systems; emphasis on contracts; } \\
\text { prominence of the individual; freedom of decision-making; } \\
\text { liberalism; isolated actors; network-based governance; belief in the } \\
\text { free market. }\end{array}$ \\
\cline { 2 - 3 } $\begin{array}{l}\text { Communitarian** } \\
\text { (coordinated market } \\
\text { economies) }\end{array}$ & $\begin{array}{l}\text { Importance of social groups and laws for the community; } \\
\text { prominence of the collective; solidarity; interconnected actors; } \\
\text { governmental intervention in industry; partnership-based } \\
\text { governance; regulated market instead of free market. }\end{array}$ \\
\hline Developing Countries & $\begin{array}{l}\text { High levels of uncertainty in businesses transactions; volatility and } \\
\text { strong growth based on consumer's demands; unstable political } \\
\text { systems; weak legal systems. Personal networks have a major role } \\
\text { in the commercial transactions. }\end{array}$ \\
\hline
\end{tabular}

Note. Source: elaborated from Choi, C. J., Kim, S. W., \& Kim, J. B. (2009). Globalizing business ethics research and the ethical need to include the bottom-of-the-pyramid countries: redefining the global triad as business systems and institutions. Journal of Business Ethics, 94(2), 299-306. http://doi.org/10.1007/s10551-009-0258-y; Matten, D., \& Moon, J. (2008). "Implicit" and "explicit" CSR: a conceptual framework for a comparative understanding of corporate social responsibility. Academy of Management Review, 33(2), 404-424. http://doi.org/10.2307/20159405.

* Examples: USA and UK; ** Examples: continental Europe and Japan.

\section{Developing countries}

As indicated in Table 3, the formal institutions of developing countries tend to be marked by low levels of reliability. The corruption, slowness of legal proceedings, excess of safeguards available to borrowers, political instability, eventual arbitrary interventions of the State on the economy, and other flaws in the regulatory systems all decrease MFIs' ability to guarantee the execution of lending contracts accorded between them and their borrowers (Churchill, 1999). The enforcement capacity of these organizations is considerably reduced and, consequently, they bear higher transactional risks (Stiglitz, 1990).

These countries' institutional environments also hinders or overburdens the screening, monitoring and enforcement activities performed by MFIs (Churchill, 1999). The insufficiency or even absence of an informational system which should report to the financial institutions, the situation of their current and potential borrowers, the cultural traditions that gives advantage to interpersonal relationships rather than the fulfillment of legal prerequisites, and the considerable informality of the economic activities are factors that increase the uncertainty level for MFIs.

Therefore, we argue that developing countries' institutional environments considerably increase the costs of the design and execution of the screening, monitoring and enforcement activities performed by the MFIs. These higher costs are justified by the fact that the support provided by the external institutions to these activities is inconstant, null or, sometimes, even negative.

North (1991) and Putnam (1993) refer to the same example to highlight the historical roots of these institutional weaknesses and to illustrate how the social and economic institutions that obstruct a nation's development are born and perpetuated. Both authors emphasize the prominence of personal relations over those somehow mediated by formal institutional devices in Latin American countries. According to Putnam (1993), the general mistrust towards formal institutions is justified by their origins. Latin formal institutions (as well as the institutions of other developing countries) have not emerged from what the author calls great civic traditions, an archaic form of social capital. That is, developing countries usually lack the antecedents for the creation of a generalized (institutional) social capital and 
this lack must be the main cause of their formal institutions' inefficiency. This vicious circle has reinforced itself throughout the centuries: the formal institutions are socially and economically inefficient because they are not the products of precedent civic traditions which, in their turn, are not able to blossom due the current pathological institutional fostering of clientelism, exploitation and amoral individualism which inhibit cooperation (Putnam, 1993). This argument is supported by Knack and Keefer (1997): both authors suggested that more developed countries are, in general, those having higher degrees of generalized trust.

Thus, considering that (a) the historical civic traditions studied by Putnam (1993) and the efficient formal institutions derived from these traditions require decades (maybe centuries) to be constituted; and that (b) the formal institutions of developing countries are not sufficient to guarantee the viability of microfinance operations (considering the risks involved and the costs to control them), we present our first proposition:

Proposition 1: In developing countries, the stocks of individual and network social capital are the most efficient for LGs in the screening, monitoring and enforcement activities (for decreasing MFIs' transaction costs, and moral and adverse selection risks).

As aforementioned, the use of stocks of individual and network social capital leads to the benefits (higher information symmetry, creation and use of informal reward and punishment systems, and increase of trust and solidarity levels) provided by the local interpersonal networks and by the individual members (neighbors, friends, family members, work colleagues, etc.) (Coleman, 1988). Knack and Keefer (1997) corroborate this perspective when they highlight the importance of interpersonal trust for the development of poorer countries.

Thus, the use of these stocks of individual and network social capital is expected to bolster the efficient absorption of the screening, monitoring and enforcement activities by the LGs. However, following the basic assumptions of transaction costs theory, we must consider that the use of these stocks of social capital implies a higher contractual specificity, since one single institutional arrangement for mediating the transactions of MFIs and borrowers will not be sufficient for all LGs. Consequently, MFIs must either design and share the three activities (screening, monitoring and enforcement) based on the specific level of internal social capital of each individual LG. Otherwise it would be assumed that all LGs hold a similar level of social capital, which is not realistic.

At the same time, this specificity necessitates evaluation of the borrowers' characteristics and their stocks of individual social capital. Ostrom $(1998,2000)$ stresses the importance of assuring proportionately higher numbers of cooperative and punitive compared to rational-egoistic individuals in collaborative social groups. An excess of the latter type will likely compromise the collectivity results, as long as these individuals tend to undermine the bases upon which the stocks of individual and network social capital are built. In order to reduce this risk, the MFIs must employ screening mechanisms that allow them to discern the characteristics of the borrowers forming their LGs. Nevertheless, we argue that although the MFIs absorb the transaction costs derived from these screening tools, these costs will tend to be lower than those necessary to evaluate individual potential borrowers not part an LG, since the groups share some of these costs with the MFIs.

\section{Developed countries (Anglo-Saxon and communitarian countries)}

Before individually analyzing the specificities of Anglo-Saxon versus communitarian environments, we discuss their common ground: the stability and reliability of their institutional environments. As shown by North (1991), Putnam (1993), Matten and Moon (2008), Choi, Kim and Kim (2009), the majority of developed countries possess consolidated and efficient institutions (formal and informal) that offer safe and predictable foundations upon which individual and collective actors can establish economic transactions. Private property is guaranteed and enforcement of contracts is easier and more cost-effective. 
Thus, the robustness of their institutional systems reduces the MFIs' enforcement costs, since these organizations can use an efficient legal system to ensure contract fulfillment. The institutional environment of developed countries also fosters a better information flow between actors (e.g. MFIs and borrowers) engaged in economic transactions. The interaction among information hubs, such as professional associations, entrepreneurship agencies, financial institutions and insurance companies facilitates the screening and monitoring of the micro-entrepreneurs, the main clients of MFIs. Additionally, this environment might also work as a form of support network for small businesses, increasing their chances of survival.

Like the deep-rooted institutions of developing countries, developed countries' institutions have historical antecedents. North (1991) argues that the main cause of the high degree of development of these countries is the adoption of three institutional innovations: (a) those that increase the capital mobility; (b) those that reduce the information costs; and (c) those that enable the sharing of risks.

However, although both Anglo-Saxon and communitarian countries have reached institutional maturity through these advances, there are still important differences. While the first type of country works with atomized individuals, each somewhat distant from his/her surroundings, communitarianism puts more attention on the social contexts of individuals as well as the relationships amongst them (Choi, Kim, \& Kim, 2009).

This ontological divergence has produced characteristic consequences for each type of institutional environments. Anglo-Saxon countries advocate the individual freedom ideal, the private property imperative, the free market and an efficient legal system as the key institutions for the regulation of their social and economic transactions (Choi et al., 2009). In contrast, the communitarian countries have built their institutional environment upon more collectivist values, such as community, solidarity and partnership (Choi et al., 2009). Although communitarian countries also value the importance of a reliable legal system, they tend to emphasize the ancestral customs that gave rise to their economic systems (Choi et al., 2009). Moreover, these are considerably regulated and the government and other public agencies intervene more intensely in the market than is the case in AngloSaxon countries.

These different institutional environments have different effects on social capital. The social ideals of communitarian countries are more closely related to the concept of social capital than is the ideal of Anglo-Saxon individualism, with its free market prominence and competition. Putnam (1993) and Adler (2001), for example, explain how the rules and values of the free market might negatively interfere in the elements preceding the formation and diffusion of social capital - such as the social connections based on mutual trust, and the cohesive and cooperative social networks - throughout a society.

Because Anglo-Saxon countries prefer using market and hierarchical formal mechanisms to coordinate their economic transactions, we argue that the stocks of institutional social capital play a less important role in the operation of MFIs' institutional arrangements and LGs and in performance of the screening, monitoring and enforcement activities. However, if there are no stocks of individual or network social capital among the LGs' borrowers, the transference of these activities from the MFIs to the LGs will be inefficient, as the participants will not have the necessary social mechanisms at their disposal for the efficient performance the three activities.

Moreover, we emphasize that although these stocks are also needed in this case, as happens in the developing countries, Anglo-Saxon countries' institutional environments produce different implications for the microfinance arrangements and for the screening, monitoring and enforcement activities. While developing countries do not present a formal institutional environment to support MFIs in the performance of these three activities, Anglo-Saxon countries usually have a robust and reliable legal system that strengthens, even if partially, their capability for performing these actions. Therefore, we present proposition 2. 
Proposition 2: In Anglo-Saxon developed countries, the stocks of individual and network social capital - supported by formal devices - are the most efficient ones for LGs to perform the screening, monitoring and enforcement activities (for the reduction of MFIs' transaction costs, and moral and adverse selection risks).

The communitarian countries' institutional context is the last to be discussed. As mentioned previously, the communitarian institutional environment is formed by elements and values underpinning social capital. Therefore, its business systems are modeled on values such as generalized trust, solidarity and collectivism, and are supported by coordinated social groups organized within aggregated governance systems. Thus, this is the type of environment that, in theory, should make better use of all the stocks of social capital to enhance the performance of screening, monitoring and enforcement activities.

Ancestral social institutions (dwelling within the socially embedded level) have over the centuries cultivated a generalized trust and the prominence of collective action. These belief systems and social structures have given rise to formal institutions that currently perform relevant roles in the coordination of economic agents' actions. Consequently, the dysfunctional effects observed in the poorest countries (such as social verticalization, corruption and institutional inefficiency) are minimized in the communitarian countries. This conjecture justifies the high levels of generalized trust, the respect for civic rules and the low levels of corruption, as showed by Knack and Keefer (1997) in the European communitarian countries and in Japan. This institutional landscape also enables more favorable conditions for the growth of the stocks of institutional social capital which might, in their turn, reinforce the stocks of individual and network social capital.

The larger stocks of institutional social capital have the effect of decreasing the setup costs in the design and institutional arrangement of MFIs and LGs. As long as the communitarian countries' social structures have an historically built institutional efficiency which diminishes the information asymmetries, provides informal systems of reward and punishment, and fosters generalized trust and solidarity (Putnam, 2002), we can expect that the MFIs will not have a strong need (nor incurred cost) for checking the levels of stocks of individual and network social capitals of each LG. That is so because the existent stocks of institutional social capital enables borrowers to bring larger initial stocks of generalized trust, solidarity, collaboration and sanction capability to their LGs.

Considering these arguments, we posit that the communitarian countries provide a more receptive ground for the efficient absorption of the screening, monitoring and enforcement activities by the LGs and for the lowering of the transaction costs borne by the MFIs:

Proposition 3: In communitarian developed countries, the stocks of institutional social capital provide the conditions for the most efficient execution of screening, monitoring and enforcement activities by LGs, (thus diminishing MFIs' transaction costs and moral and adverse selection risks).

Based on the analysis of the institutional contexts of developing countries (Anglo-Saxon and communitarian), we illustrate in Table 4 our main argument: MFIs dwelling in different institutional environments require different stocks of social capital for maximizing the efficiency of their LGs.

Anglo-Saxon and developing environments are similar in that stocks of individual and network social capital are the most important mechanisms for minimizing MFIs' risks and transaction costs. However, in contrast to the MFIs situated in poorer countries, the MFIs in Anglo-Saxon countries can employ their strong formal institutional mechanisms to complement their stocks of local social capital to increase the efficiency of their LGs. The developed communitarian environments differ from both Anglo-Saxon and developing environments in that the LGs' ability to reduce MFIs' risks and transaction costs derives chiefly from their stocks of institutional social capital. 
Table 4

Influence of the Interaction of the Different Institutional Environments and the Different Stocks of Social Capital on LGs' Ability to Diminish the Transaction Costs and Risks of MFIs

\begin{tabular}{|c|c|c|c|c|}
\hline \multirow[t]{2}{*}{ Institutional Environment } & & \multicolumn{2}{|l|}{ Developed Countries } & \multirow[t]{2}{*}{ Developing Countries } \\
\hline & & Anglo-Saxon & Communitarian & \\
\hline \multirow[t]{3}{*}{ Key elements } & 1. Formal Institutional Level & High & High & Low \\
\hline & 2. Institutional Social Capital & Medium & High & Low \\
\hline & 3. Individual and Network Social Capitals & Contingent & Contingent & Contingent \\
\hline \multicolumn{3}{|c|}{$\begin{array}{l}\text { Influence of the formal institutional level on the screening, monitoring and Positive } \\
\text { enforcement activities performed by MFIs }\end{array}$} & Positive & Null-Negative \\
\hline \multirow[t]{2}{*}{$\begin{array}{l}\text { Influence of the overall } \\
\text { institutional environment on } \\
\text { the social capital }\end{array}$} & $\begin{array}{l}\text { 1. Influence of the institutional environment } \\
\text { over the stocks of institutional social } \\
\text { capital }\end{array}$ & Null-Negative & Positive & Negative \\
\hline & $\begin{array}{l}\text { 2. Most recurrent types of relationships } \\
\text { (between actors) }\end{array}$ & $\begin{array}{l}\text { Formal-Impersonal (mediated } \\
\text { by contracts) }\end{array}$ & $\begin{array}{l}\text { Formal/Informal- Personal } \\
\text { (mediated by civic norms and } \\
\text { contracts) }\end{array}$ & $\begin{array}{l}\text { Informal-Personal (mediated } \\
\text { by personalistic trust) }\end{array}$ \\
\hline \multirow{3}{*}{$\begin{array}{l}\text { Effects of the interaction } \\
\text { between the institutional } \\
\text { environment and the different } \\
\text { stocks of social capital on the } \\
\text { LGs and the screening, } \\
\text { monitoring and enforcement } \\
\text { activities }\end{array}$} & $\begin{array}{l}\text { 1. Main coordination mechanism for the } \\
\text { MFIs-borrowers** relations }\end{array}$ & $\begin{array}{l}\text { Local stocks of social capital } \\
\text { (individual and network) } \\
\text { supported by formal devices } \\
\text { (contracts). }\end{array}$ & $\begin{array}{l}\text { Stocks of institutional social } \\
\text { capital supported by eventual } \\
\text { stocks of individual and network } \\
\text { social capital }\end{array}$ & $\begin{array}{l}\text { Local stocks of individual } \\
\text { and network social capital }\end{array}$ \\
\hline & $\begin{array}{l}\text { 2. Efficiency on sharing the screening, } \\
\text { monitoring and enforcement activities with } \\
\text { the LGs }\end{array}$ & Medium & High & Medium-Low \\
\hline & $\begin{array}{l}\text { 3. Contractual specificity and transaction } \\
\text { costs absorption by the MFIs }\end{array}$ & Medium & Low & Medium-High \\
\hline
\end{tabular}

Note. * By contingent, we mean that the eventual creation of stocks of social capital depends on each LG; ** The institutional arrangement in all institutional environments is the same: an MFI which extends loans to joint liable, self-selected LGs, subjected to the same operational routine. 


\section{Discussion}

In this paper we proposed a systemized institutional view for the relations established between the institutional environments of developed countries (Anglo-Saxon and communitarian) and developing countries, and the different stocks of social capital held by microfinance LGs. Although the importance of social capital for the microfinance world is a commonly acknowledged phenomenon, there were no studies addressing the interaction between types of institutional environments and type of social capital.

We submit that the three propositions presented here will help policymakers and practitioners to identify the most suitable stocks of social capital for each institutional environment, allowing those MFIs oriented towards LGs to target their actions and resources on structures and processes that more efficiently and effectively minimize their transaction costs and risks to generate larger organizational and social gains. This systematization between the institutional environments of rich versus poor nations, social capitals and LGs can also assist in the transference of microfinance methodologies between these countries, minimizing strategic errors originating from incompatibility between the MFIs' designs, their LGs, and the institutional environments overarching them (Bhatt \& Tang, 1998).

We suggest that future studies empirically explore the propositions presented in this paper. We also encourage further studies focused on the best fit between the specific design of a group of MFIs, the social networks of their borrowers and their cognitive frameworks. Such studies could integrate the macro institutional perspective that we present here, so as to provide a broader and more robust model of the relationships between LGs, stocks of social capital and institutional environments.

The limitations of this study stem from the institutional approach that we used as a basis of analysis for LGs, stocks of social capital and institutional environments. We neither explored nor exposed the details of the economic and social conditions of poor borrowers engaged in LGs. The definition of poverty is complex and the reality of poverty is context-dependent - what is poverty in a given region might not be poverty in another. Such definition may describe various aspects of economic and social life, and can be considered from multiple perspectives (Ferreira \& Lugo, 2013).

The same observation applies to our categorization of the three different institutional contexts (Anglo-Saxon, communitarian and developing). Because we offered an institutional view of a microfinance set of relations, we have not considered the manifold variations that exist in each specific institutional environment, MFI and LG. Different volumes of stocks of social capital, combined with different local peculiarities and social actors, especially those located at the base of the social pyramid, can naturally positively or negatively affect the efficiency of the screening, monitoring and enforcement activities performed by LGs. Thus, though the characteristics of the institutional contexts described in this paper are directionally correct, they should not be taken blindly as absolutes.

\section{References}

Adler, P. S. (2001). Market, hierarchy, and trust: the knowledge economy and the future of capitalism. Organization Science, 12(2), 215-234. http://dx.doi.org/10.1287/orsc.12.2.215.10117

Adler, P. S., \& Kwon, S. (2002). Social capital: prospects for a new concept. Academy of Management Review, 27(1), 17-40. http://dx.doi.org/10.2307/4134367

Bachmann, R. (2001). Trust, power and control in trans-organizational relations. Organization Studies, 22(2), 337-365. http://dx.doi.org/10.1177/0170840601222007

Bastelaer, T. van (1999b). Does social capital facilitate the poor's access to credit? A review of the microeconomic literature [Social Capital Initiative Working Paper ${ }^{\circ}$ 8]. Social Development 
Department, Washington, DC. Retrieved from http://siteresources. worldbank.org/INTSOCIALCAPITAL/Resources/Social-Capital-InitiativeWorking-Paper-Series/SCI-WPS-08.pdf

Bastelaer, T. van (1999a). Imperfect information, social capital and the poor's access to credit. [IRIS Center Working Paper $n^{\circ}$ 234]. Social Science Research Network, Rochester, NY. Retrieved from http://papers.ssrn.com/sol3/papers.cfm?abstract_id=260058

Beckert, J. (2010). How do fields change? The interrelations of institutions, networks, and cognition in the dynamics of markets. Organization Studies, 31(5), 605-627. http://dx.doi.org/10.1177/0170840610372184

Besley, T., \& Coate, S. (1995). Group lending, repayment incentives and social collateral. Journal of Development Economics, 46(1), 1-18. http://dx.doi.org/10.1016/0304-3878(94)00045-E

Bhatt, N., \& Tang, S. (1998). The problem of transaction costs in group-based microlending: an institutional perspective. World Development, 26(4), 623-637. http://dx.doi.org/10.1016/S0305750X(98)00007-2

Bhattamishra, R., \& Barrett, C. B. (2010). Community-based risk management arrangements: a review. World Development, 38(7), 923-932. http://dx.doi.org/10.1016/j.worlddev.2009.12.017

Cassar, A., Crowley, L., \& Wydick, B. (2007). The effect of social capital on group loan repayment: evidence from field experiments. The Economic Journal, 117(517), 85-106. http://dx.doi.org/10.1111/j.1468-0297.2007.02016.x

Choi, C. J., Kim, S. W., \& Kim, J. B. (2009). Globalizing business ethics research and the ethical need to include the bottom-of-the-pyramid countries: redefining the global triad as business systems and institutions. Journal of Business Ethics, 94(2), 299-306. http://dx.doi.org/10.1007/s10551009-0258-y

Churchill, C. F. (1999). Client-focused lending: the art of individual lending. Washington, DC: Calmeadows.

Coleman, J. S. (1988). Social capital in the creation of human capital. American Journal of Sociology, 94(1), 95-120. http://dx.doi.org/10.1086/228943

Collins, D., Morduch, J., Rutherford, S., \& Ruthven, O. (2009). Portfolios of the poor: how the world's poor live on $\$ 2$ a day. New Jersey, NJ: Princeton University Press.

Ebers, M. (1999). Explaining inter-organizational network formation. In M. Ebers (Ed), The formation of interorganizational networks (pp. 3-40). Oxford: Oxford University Press.

Ferreira, F. H. G., \& Lugo, M. A. (2013). Multidimensional poverty analysis: looking for a middle ground. The World Bank Research Observer, 28(2), 220-235. http://dx.doi.org/10.1093/wbro/lks013

Fligstein, N. (2001). Social skill and the theory of fields. Sociological Theory, 19(2), 105-125. http://dx.doi.org/10.1111/0735-2751.00132

Ghatak, M. (1999). Group lending, local information and peer selection. Journal of Development Economics, 60(1), 27-50. http://dx.doi.org/10.1016/S0304-3878(99)00035-8

Ghatak, M. (2002, November). Exploiting social networks to alleviate credit market failures: on the endogenous selection of peer groups in microfinance programs. Proceedings of Conference on Credit, Trust and Calculation, Los Angeles, CA, USA. 
Ghatak, M., \& Guinnane, T. W. (1999). The economics of lending with joint liability: theory and practice. Journal of Development Economics, 60(1), 195-228. http://dx.doi.org/10.1016/S03043878(99)00041-3

Granovetter, M. (2005). The impact of social structure on economic outcomes. Journal of Economic Perspectives, 19(1), 33-50. http://dx.doi.org/10.1257/0895330053147958

Greif, A. (1994). Cultural beliefs and the organization of society: a historical and theoretical reflection on collectivist and individualist societies. Journal of Political Economy, 102(5), 912-950. http://dx.doi.org/10.1086/261959

Grossman, S. J., \& Stiglitz, J. E. (1980). On the impossibility of informationally efficient markets. The American Economic Review, 70(3), 393-408.

Hung, C. R. (2006). Rules and actions: determinants of peer group and staff actions in group-based microcredit programs in the United States. Economic Development Quarterly, 20(1), 75-96. http://dx.doi.org/10.1177/0891242405279361

Knack, S., \& Keefer, P. (1997). Does social capital have an economic payoff? A cross-country investigation. The Quarterly Journal of Economics, 112(4), 1251-1288. http://dx.doi.org/10.2307/2951271

Larance, L. Y. (1998). Building social capital form the center: a village-level investigation of Bangladesh's Grameen Bank [Working Paper n ${ }^{\circ}$ 98-4]. Center for Social Development, St. Louis, MO, USA.

Lavoie, F. (2009). Conditions facilitating the replication of microcredit methodologies (Master's thesis). HEC Montréal, Montréal, Quebec, Canada.

Matten, D., \& Moon, J. (2008). "Implicit" and "explicit" CSR: a conceptual framework for a comparative understanding of corporate social responsibility. Academy of Management Review, 33(2), 404-424. http://dx.doi.org/10.2307/20159405

McEvily, B., Perrone, V., \& Zaheer, A. (2003). Trust as an organizing principle. Organization Science, 14(1), 91-103. http://dx.doi.org/10.1287/orsc.14.1.91.12814

Morduch, J. (1999). The microfinance promise. Journal of Economic Literature, 37(4), 1569-1614. http://dx.doi.org/10.1257/jel.37.4.1569

North, D. C. (1991). Institutions. The Journal of Economic Perspectives, 5(1), 97-112. http://dx.doi.org/10.1257/jep.5.1.97

Ostrom, E. (1998). A behavioral approach to the rational choice theory of collective action: presidential address, American political science association, 1997. The American Political Science Review, 92(1), 1-22. http://dx.doi.org/10.2307/2585925

Ostrom, E. (2000). Collective action and the evolution of social norms. The Journal of Economic Perspectives, 14(3), 137-158. http://dx.doi.org/10.1080/19390459.2014.935173

Ostrom, E., Ahn, T. K., \& Olivares, C. (2003). A social science perspective on social capital: social capital and collective action. Revista Mexicana de Sociologia, 65(1), 155-233. http://dx.doi.org/10.2307/3541518

Ouchi, W. G. (1980). Markets, bureaucracies and clans. Administrative Science Quarterly, 25(1), 129141. http://dx.doi.org/10.2307/2392231

Pischke, J. D. V. (1991). Finance at the frontier: debt capacity and the role of credit in the private economy. Washington: World Bank. 
Portes, A. (1998). Social capital: its origins and applications in modern sociology. Annual Review of Sociology, 24(1), 1-24. http://dx.doi.org/10.1146/annurev.soc.24.1.1

Putnam, R. D. (1993). Making democracy work: civic tradition in modern Italy. New Jersey: Princeton University Press.

Putnam, R. D. (2002, January 18). Bowling together. The American Prospect. Retrieved from http://prospect.org/article/bowling-together-0

Rankin, K. N. (2002). Social capital, microfinance, and the politics of development. Feminist Economics, 8(1), 1-24. http://dx.doi.org/10.1080/13545700210125167

Sengupta, R., \& Aubuchon, C. (2008). The microfinance revolution: an overview. Federal Reserve Bank of St. Louis Review, 90(1), 9-10. http://dx.doi.org/10.3886/ICPSR21580

Serageldin, I., \& Grootaert, C. (2000). Defining social capital: an integrating view. In P. Dasgupta \& I. Serageldin (Eds.), Social capital: a multifaceted perspective (pp. 40-58). Washington: World Bank.

Spence, M. (1973). Job market signaling. The Quarterly Journal of Economics, 87(3), 355-374. http://dx.doi.org/10.2307/1882010

Stigler, G. J. (1970). The optimum enforcement of laws. Journal of Political Economy, 78(3), 526-536. http://dx.doi.org/10.1086/259646

Stiglitz, J. E. (1987). Economic organization, information and development. In H. Chenery \& T. N. Srinivasan (Eds.), Handbook of development economics (Chap. 5, pp. 93-160). North-Holland: Elsevier.

Stiglitz, J. E. (1990). Peer monitoring and credit markets. The World Bank Economic Review, 4(3), 351366. http://dx.doi.org/10.1093/wber/4.3.351

Stiglitz, J. E., \& Weiss, A. (1981). Credit rationing in markets with imperfect information. The American Economic Review, 71(3), 393-410. http://dx.doi.org/10.1126/science.151.3712.867-a

Swain, N. (2003). Social capital and its uses. European Journal of Sociology, 44(2), 185-212. http://dx.doi.org/10.1017/S0003975603001243

Tassel, E. V. (1999). Group lending under asymmetric information. Journal of Development Economics, 60(1), 3-25. http://dx.doi.org/10.1016/S0304-3878(99)00034-6

Williamson, O. E. (1991). Comparative economic organization: the analysis of discrete structural alternatives. Administrative Science Quarterly, 36(2), 269-296. http://dx.doi.org/10.2307/2393356

Williamson, O. E. (2000). The new institutional economics: taking stock, looking ahead. Journal of Economic Literature, 38(3), 595-613. http://dx.doi.org/10.1257/jel.38.3.595

Yunus, M. (2007). Banker to the poor: micro-lending and the battle against poverty. New York, NY: Public Affairs. 


\section{Authors' Profiles}

Diego A. B. Marconatto Av. Unisinos, 950, Cristo Rei, Prédio da Escola de Gestão e Negócios, 93022-000, São Leopoldo, RS, Brasil. E-mail: dmarconatto@unisinos.br

Luciano Barin-Cruz

3000 Chemin de la Côte-Sainte-Catherine, H3T 2A7, Montreal, Quebec, Canadá. E-mail: luciano.barin-cruz@hec.ca

Eugenio Pedrozo

Rua Washington Luiz, 855, 90010-460, Porto Alegre, RS, Brasil. E-mail: eapedrozo@ea.ufrgs.br 